\title{
INTENSITAS MENONTON TAYANGAN KEKERASAN DI TELEVISI \\ DAN KECENDERUNGAN AGRESIVITAS PADA REMAJA \\ (Studi Pada Siswa Kelas IX MTs Negeri 1 Bangil)
}

Iqbal Fikri

Mahasiswa Universitas Muhammadiyah Sidoarjo.

Telp. 031-8945444

\section{ABSTRACT}

Many violence cases as brawls and fights whose committed by juveniles were caused by many factors. This study aimed to find out the relationship between the intensity of watching violence on television with aggressiveness tendencies in adolescents. This study used a quantitative correlation approach that using the intensity watching violence on television as an independent variable $(\mathrm{X})$ and the tendency of aggressiveness as the dependent variable $(\mathrm{Y})$. The sampling technique used random sampling to 69 students of class IX in MTs Negeri 1 Bangil. Measurement of variables used both of two psychological scales that constructed by the researchers, namely the intensity of watching violence on television scale and aggressiveness tendencies scale. Correlation technique of product moment from Person was used to analyze data which of calculation helped by SPSS 16.0 for Windows. The results showed that $(\mathrm{r})=0.404 ; \rho=0.001<\rho=0.01$. It means, there is a significant relationship and positive, the higher of the intensity of watching violence on television, the higher of the aggressiveness tendencies in adolescents and vice versa.

Keywords: Intensity of Watching Violence on Television, Aggressiveness tendencies, adolescence.

\section{ABSTRAK}

Seringkali terjadi kasus kekerasan seperti tawuran dan perkelahian yang dilakukan oleh remaja disebabkan oleh banyak faktor. Penelitian ini bertujuan untuk mengetahui adanya hubungan antara intensitas menonton tayangan kekerasan di televisi dengan kecenderungan agresivitas pada remaja Penelitian ini menggunakan pendekatan kuantitatif korelasional dengan intensitas menonton tayangan kekerasan di televisi sebagai variabel independen (X) dan kecenderungan agresivita sebagai variabel dependen (Y). Teknik sampling menggunakan random sebanyak 69 siswa kelas IX MTs Negeri 1 Bangil. Pengukuran variabel penelitian menggunakan skala psikologi yang dikonstruksikan sendiri oleh peneliti dengan skala intensitas menonton tayangan kekerasan di televisi dan skala kecenderungan agresivitas. Analisa data menggunakan teknik korelasi product moment pearson yang dihitung dengan SPSS 16.0 for Windows, diperoleh hasil koefisien korelasi (r) $=0,404 ; \rho=0,001<\rho=0,01$. Nilai korelasi bertanda positif artinya ada hubungan yang signifikan, yakni semakin tinggi intensitas menonton tayangan kekerasan di televisi maka semakin tinggi kecenderungan agresivitas pada remaja dan sebaliknya.

Kata kunci : Intensitas Menonton Tayangan Kekerasan di Televisi, Kecenderungan Agresivitas, Remaja

\section{PENDAHULUAN}

Maraknya aksi kekerasan yang terjadi di masyarakat lebih banyak ditayangkan secar langsung oleh media televisi baik itu tawuran pelajar, kerusuhan massa atau film dan sinetron yang mengandung kekerasan. Hal ini seharusnya menjadi pertimbangan dan perhatian bagi kita semua. Hampir pemberitaan yang 
demikian menjadi menu utama yang disajikan di televisi. Selain berita yang banyak diwarna oleh tindakan anarkis para demonstran hingga liputan kriminal, televisi kita masih menawarkan tayangan film-film asing yang tidak lepas dari adegan memukul, menendang, adu tembak, hingga darah yang berceceran sebaga hiburan. Seolah tidak ado film lain yang men. Seolah tidak ad film lain ya patut untuk dihadirkan di ruang keluarg penonton Indonesia.

Data dari Badan Informasi Publik (BIP) Depkominfo dalam kurun waktu Januar sampai Februari tahun 2007, menurut catatan persentase tayangan kekerasan fisik yang terjadi dilayar kaca mencapai $47,41 \%$, sedangkan tayangan kekerasan psikis sebanyak $36,8 \%$ (http://depkominfo com, 2009). Jumlah 36.8\% (hip://d pkominfo com, 2009$)$ Jumlah . Hasil dat di atas dapat diambil kesimpulan bahw tayangan kekerasan sangat mendominasi tayangan televisi Indonesia. Hal ini sangat menghawatirkan dimana sebagian waktu, gunakan untuk menonton televisi. Dampak dar tayangan kekerasan tersebut dapat mempengaruhi penonton khususnya para remaja. Hasil penelitian Liebert (1972) menyimpulkan bahwa tayangan kekerasan di televisi mungkin membantu menyebabkan perilaku agresif dari membantu menyet

Soetjiningsih (2004) menyatakan masa maja merupakan masa peralihan antara mas anak-anak yang dimulai saat terjadinya kematangan seksual yaitu antara usia 11 atau 12 tahun sampai dengan 20 tahun, yaitu masa menjelang dewasa muda. Pada masa remaja awal kematangan psikologis anak belum matang, mereka cenderung masih dalam pencarian jati diri Peran lingkungan sangat pencarian jati psikologis ngan psikologis mereka. Apabila remaja terbiasa dengan kekerasan yang merek saksikan dalam tayangan televisi, hal tersebu dapat dikhawatirkan akan menyebabkan mereka cenderung memiliki agresivitas yan tinggi. Hal demikian dikarenakan merek terbiasa dengan kekerasan dalam kehidupan sehari-hari yang dipelajari melalui tayangan- tayangan kekerasan di televisi. Tayangan ayangan tersebut bisa berupa tayangan kekerasan fisik maupun verbal. Tayangan kekerasan fisik berupa tendangan, pukulan, perkelahian, menampar dan lain -lain, adapun tayangan kekerasan verbal berupa makian dan ejekan.

Intensitas dalam menonton tayangan kekerasan juga dapat berdampak terhadap penontonnya. Orang yang sudah terbiasa menyaksikan kekerasan di televisi, dapat menjadi kurang peduli terhadap kekerasan yang terjadi di dunia nyata. Inilah yang disebu dengan efek desensitisation tayangan kekerasan di televisi (Pikiran Rakyat, 2006). Efek desensitisation adalah pengurangan respon emosional terhadap kekerasan di televisi (Baron \& Byrne, 2000)

Intesitas berarti kualitas dari tingkat kedalaman, yakni kemampuan, kekuatan, daya atau konsentrasi terhadap sesuatu atau tingkat keseringan atau kedalaman cara atau sikap, perilaku seseorang. Menonton berarti aktivitas melihat sesuatu dengan tingkat perhatia tertentu (Danim, 1995). Menonton televis yaitu aktivitas melihat siaran televisi sebagai media audio visual dengan tingkat perhatian tertentu. Televisi adalah alat elektronik yan berfungsi menyebarkan gambar can dikuti diikut oleh suara tertentu. Pada dasarnya sama dengan gambar hidup bersuara (Danim, 1995).

Secara definitif, intensitas menonton tayangan kekerasan di televisi adalah tingkat keseringan atau kedalaman seorang remaj dalam menonton atau melihat tayangan $\mathrm{d}$ televisi yang menampilkan adegan-adegan kekerasan baik berupa kekerasan fisik (seperti; merusak, menendang, memukul) maupun kekerasan verbal (seperti, mencaci maki, mengumpat, mengej, maki (a) jea mangan cilo acar film kartun anak, berita kriminal, dan juga sinetron-sinetron yang yang banyak menyajikan adegan-adegan kekerasan di dalamnya.

Intensitas menonton dapat dihitun memakai parameter yakni frekwensi, durasi berkaitan dengan waktu, yakni jumlah menit dalam setiap penayangan dan tingkat attensi pemirs. Berdasarkan penelitian Sulistyadew (1995), intensitas menonton diuku berdasarkan;

a. Frekwensi keseringan remaja menonton tayangan kekerasan. Pengukuran dilakukan dengan berapa kali remaja menonton tayangan kekerasan dalam sehari. Penelitian kal ini digunakan minimal 2 kali sehari.

b. Durasi lama tayangan kekerasan yang ditonton remaja setiap kalinya. Pengukuran dilakukan dengan berapa lama remaja menonton tayangan kekerasan. Penelitian ini menggunakan minimal 1 jam dalam sehari.

c. Atensi (perhatian) adalah proses menta ketika stimuli atau rangkaian stimuli menjadi menonjol dalam kesadaran pada saa stimuli lainnya melemah (Anderson dalam Rakhmat, 2005).

Hasil Survei Sosial Ekonomi Daerah (SUSEDA), untuk tahun 2009 hanya sekita 5,31 juta atau sekitar $15,37 \%$ penduduk yang suka membaca, selebihnya lebih banyak diluangkan untuk menonton tayangan televis (http://depkominfo.com, 2009). Adanya unsur hiburan yang semakin beragam, kreatif dan menarik dalam acara televisi merupakan salah satu daya tarik utama, sehingga banyak remaja yang menggemarinya. Kegemaran remaja yan demikian, dapat saja membuatnya menonton acara-acara yang mengandung adegan kekerasan baik disengaja maupun tidak disengaja.

Kebiasaan menonton tayangan keke-rasan dapat mengarahkan pada remaja untuk berperilaku agresif. Pengaruh tayangan tersebut dapat berawal dari perubahan sikap remaja terhadap tayangan kekerasan yan nantinya kecenderungan tersebut dimunculkan dalam bentuk perilaku agresif. Kecenderungan merupakan predisposisi (kesiapan oran bersangkutan untuk bertindak dalam menghadapi obyek sikap) dan ini dipengaruhi oleh kognisi dan perasaan (Istiqomah, dkk, 1998). Hal ini berarti, kecenderungan berperilaku agresif adalah kesiapan seseoran untuk berperilaku agresif yang dipengaruhi oleh kognisi dan perasaan orang tersebut.
Berkowitz (2003) menyatakan bahwa agresif merupakan salah satu perilaku yang dimanifestasikan dalam bentuk menyerang pihak lain dengan tujuan tertentu. Perilak agresif dapat berbentuk tindakan fisik atau nonfisik (verbal atau nonverbal), secar langsung atau tidak langsung, secara individua cara reaktif atau proaktif, dan .

Agresivitas diukur dengan adanya kecenderungan untuk berperilaku yang bertujuan untuk melukai orang lain. Skala tersebut berisi pernyataan yang dapat menggambarkan kecenderungan individu untuk menyerang orang atau pihak lain secara verbal maupun fisik, baik yang dilakukan secara langsung maupun tidak langsung atau simbolik sehingga mengakibatkan rasa sakit atau luka yang bersifat fisik agresi (Wiadi, 1996).

Perilaku agresvitas muncul diawali dengan adanya niat untuk melakukan agresivita tersebut yang apabila niat tersebut diperkua oleh faktor -faktor yang dapat memicu, mak akan terjadilah perilaku agresivitas. Sebaliknya, jika niat tersebut tidak ada yan mendukung, maka akan kecil kemungkinan untuk terjadinya perilaku agresivitas tersebut (Dayakisni, 2006)

Faktor penyebab agresifitas pada remaja dapat disebabkan oleh banyak hal, salah satunya adanya pengaruh dari tayangan kekerasan di televisi yang ditonton remaja. Banyaknya memori kekerasan yang tersimpan di otak, membuat para remaja ini bersifat sang permisif terhadap kekerasan yang terjadi $\mathrm{d} i$ ingkungannya. Bahkan terkadang sangat agresif, sebagai contoh banyak diberitakan $\mathrm{d}$ media massa, seorang pelajar SMP yang menuhanya ingin handiri sampai tewa

Hampir setiap hari kasus kenakalan remaja selalu kita temukan di media massa, dimana sering terjadi di kota-kota besar seperti Jakarta, Surabaya dan Medan. Salah satu wujud dari kenakalan remaja adalah tawuran yang dilakukan oleh para pelajar atau remaja.

Berdasarkan hasil wawancara yang dilaku- 
kan peneliti terhadap guru di MTs Negeri 1 Bangil didapatkan keterangan yang menunjukkan adanya kasus kenakalan remaja pada siswa-siswa di sekolah. Beberapa kasu diantaranya sampai ada siswa yang di keluarkan dari sekolah karena sudah melangga peraturan sekolah. Hal tersebut menjadi perenelitian di sekolah tersebut untuk melihat apakah ada hubungan antara intensitas menonton tayangan kekerasan di televisi dengan kecenderungan agresifitas pada remaja di sekolah tersebut.

\section{METODE PENELITIAN}

Penelitan ini menggunakan pendekatan kuantitatif korelasional, yakni penelitian yan bertujuan untuk mendeteksi sejauh man rasian vengan vaias- va dengan variasi- variasi pada satu atau lebih

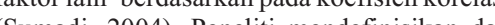
(Sumadi, 2004). Peneliti mendefinisikan da mengukur variabel secara kuantitatif, karen memungkinkan dapat melukiskan da merangkum hasil penelitian eksperimenta yang telah dilakukan serta menyimpulkan data yang diperoleh dalam sampel yang berlaku bagi populasi (Faisal, 2005).

Teknik statistik yang digunakan dalam perhitungan hasil data adalah tehnik korelasi yakni suatu teknik statistik parametrik yang digunakan untuk menguji hubungan data rasio ata interval serta berfungsi untuk mengetahui besa kontribusi variabel independen terhadap perubahan variabel dependen (Sugiyono, 2008). Perhitungan analisa data dilakukan dengan menggunakan bantuan program SPSS versi 16.0 for windows.

Penelitian ini dilaksanakan pada siswa kelas IX MTs Negeri 1 Bangil sebanyak 350 siswa sebagai populasi penelitian. Penentuan sampel penelitian menggunakan teknik random sampling yakni menentukan sampel yang dilakukan secara acak tanpa adanya katego-risas tertentu (Sugiyono, 2008). Pertimbangan Jumlah subyek yang kurang dari 100 orang, mak lebih baik jumlah itu diambil semua dan apabila besar atau lebih dari 100 orang maka dapa diambil antara $10 \%-15 \%$ atau $20 \%-25 \%$ atau lebih (Arikunto, 1998). Berdasarkan acuan tersebut, maka pengambilan sampel pada penelitian ini menggunakan 10\%-15\% karena jumlah populasi lebih besar dari 100 orang yakni 350 orang sehingga sampel yang diambil sejumlah 69 orang.

Alat pengumpul data pada penelitian in menggunakan dua skala psikologis yang dikonstruksika dengan skala kecenderungan agresivitas dengan model skala Likert yang suda dimodifikasi dengan menghilangkan jawaban ragu-ragu dengan pertimbangan agar subjek tidak memberikan jawaban yang mengumpul d tengah (Hadi, 2000). Masing- masing indikato terdiri dari item favourable dan item unfavorable serta menyediakan empat alternatif jawaban yang terdiri dari Sangat Sesuni (SS), Sesua (S), Tidak Sesua (TS), Sangat (Siduk Sest (STS). Pengat Tirik Sesuai (STS). Pemberian skor pada skal ini bergerak dari 4 sampai 1 untuk item yang mendukung (favourable), sedangkan untuk skor item yang tidak mendukung (unfavourale) bergerak dari 1 sampai 4

Kedua menggunakan skala intensitas menonton tayangan kekerasan berupa skala Guttman yakni pengukuran yang didapa dengan jawaban yang tegas, yaitu "ya atau tidak", "benar atau salah", "positif ata crif", "bn lain. Data yang diper me (dea a (dua alternatif). Pada penilaian skala Guttman, jika jawaban "ya" mendapat skor tertinggi yatu 1 dan jika menjawab "tidak" mendapat sko terendah yaitu 0 (Sugiyono, 2008)

Pengujian validitas yang dilakukan adalah dengan menggunakan validitas isi yan diestimasi lewat pengujian terhadap isi tes dengan analisis rasional lewat pengujian erhadap isi tes dengan analisis rasional ata (Azwas, 2009). Hat (le orang ahli dan disetujui untuk dilakukan uji coba kepada sampel lain yang representatif dengan sampel penelitian serta diuji secara statistik dengan bantuan program kompute SPSS 16.0 for Windows.

Hasilnya diperoleh dengan melihat hasil $\mathrm{r}_{\text {himute }}$ yang dibandingkan dengan kriteria yang digunakan untuk item yang dinyatakan valic dalam uji coba validitas $\mathrm{r}_{\text {hitung }}>\mathrm{r}_{\text {tabel }}=0,2369(\mathrm{df}$ 67, $\alpha=0,05$ ) (Pratisto, 2004). Berdasarkan kriteria ini, hasil uji coba didapatkan item yan valid berjumlah 20 item untuk skala intensitas menonton tayangan kekerasan di televisi dan 26 item untuk Nilai valid Nayanga kekerasan di televis ber 0,250 ke arah 0,661 dan untuk skala kecenderungan agresifitas bergerak dari $0,246 \mathrm{k}$ arah 0,620

Pada perhitungan uji reliabilitas, Pratisto (2004) menyatakan bahwa alat ukur dikataka reliabel jika koefisien korelasinya bernilai positif dan koefisien korelasinya lebih besar dari $r_{\text {tabel }}\left(r_{\text {ath }}>r_{\text {tabes }}\right)$. Hasil uji reliabilitas dari skala intensitas menonton tayangan kekerasan di televisi diperoleh $r_{a \text { pha }}=0,845$, sedangkan untuk skala kecenderungan agresivitas diperoleh $\mathrm{r}_{\text {alpha }}=0,863$. Azwar (2008) menyatakan bahwa reliabilitas di atas 0,8 adalah baik. Hal ini dapat disimpulkan bahwa kedua skala tersebut dikatakan valid dan reliabel.

\section{HASIL PENELITIAN DAN}

Perhitungan hasil analisa data dilakukan dengan melakukan perhitungan uji asum sebagai syarat dalam melakukan uji statistik parametrik, yakni

a. Uji normalitas data dimaksudkan untuk memperlihatkan bahwa data sampel berasa dari populasi yang berdistribusi norma (Candiasa, 2004). Teknik yang digunakan dalam penelitian ini adalah uji KolmogorovSmirnov, karena didasarkan pada jumlah sampel yang besar yakni lebih dari 50 (Dahlan, 2009) yang dibantu dengan program SPSS 16.0 for Windows. Hasil uji Kolmogorov-Smirnov diperoleh untuk skal Kolnoger menton tayangan kekerasan di televisi $\rho=0,088$ dan untuk skala kecenderungan agresivitas $\rho=0,514 ; \operatorname{dan} \rho>0,05$, maka kedua data tersebut berdistribus normal (Uyanto, 2009).

b. Uji linearitas dimasudkan untuk mengetahui hubungan antar variabel yang hendak dianalisis itu mengikuti garis lurus. Jadi, peningkatan atau penurunan kuantitas disatu variabel, akan diikuti secara linea oleh peningkatan atau penurunan kuantitas variabel lainnya (Candiasa, 2004). Pada uji linearitas dalam penelitian ini menggunakan program SPSS 16.0 for Windows, ditunjukkan pada tabel anova dengan nilai $F$ $=1,691$ dengan $\rho=0,094 ; \rho>0,05$. Hal ini dapat disimpulkan bahwa kedua data skala tersebut bersifat linear.

Perhitungan korelasi untuk kedua data tersebut dengan melihat pada hasil analisis koefisien korelasi variabel intensitas me-nonton tayangan kekerasan dengan kecenderungan agresifitas, yang diperoleh hasil koefisie korelasi $=0,404$ lebih besar dari rtabel $=0,236$ $(\mathrm{df}=67 \alpha=0,05)$ dengan $\rho=0,001 ; \rho<0,01$. Artinya hubungan kedua variabel tersebut signifikan. Nilai koefisien korelasi intensitas menonton tayangan kekerasan de-ngan kecenderungan agresifitas sebesar 0,404 yang bertanda positif, antinya menujukkan ara yang positif, yakni semakin tinggi nila entens semakin tinggi pula nilai kecenderungan agresifitas dan begitu pula sebaliknya, bila nila intensitas menonton tayangan kekerasan semakin rendah maka semakin rendah nila kecenderungan agresifitas. Hal ini dapa disimpulkan bahwa hipotesa dalam penelitian ini dapat diterima.

\section{KESIMPULAN}

Hasil penelitian ini mendukung hasil penelitian Lembaga Kesehatan Mental Nasional Amerika (2010), yang dilakukan dalam skal besar selama sepuluh tahun. Hasilnya menunjukkan bahwa kekerasan dalam program televisi menimbulkan perilaku agresif pada anakanak dan remaja yang menonton program tersebut. Ron Solby dari Universitas Harvard menjelaskan, ada empat macam dampak kekerasan terhadap perkembangan kepribadian dampak korban di mana sifat jahat dari anak 
semakin meningkat, dampak korban di mana anak menjadi penakut dan semakin sulit mempercayai orang lain, dampak pemerhati yaitu anak menjadi makin kurang peduli terhadap kesulitan orang lain dan dampak nafs dengan meningkatnya keinginan anak untuk melihat atau melakukan kekerasan dalam mengatasi setiap persoalan.

Menurut teori perkembangan anak, tayangan di televisi yang mengandung kekerasan tidak seharusnya ditonton. Hal ini dikarenakan tayangan tersebut mengandung unsur kekerasan yang frekuensi kemuncu-lannya cukup tinggi, sehingga keberadaannya bukan lag dimaksudkan untuk mengem-bangkan cerita, namun sudah menjadi inti atau bagian utama. Kekerasan-kekerasan yang demikian pun tidak hanya dinilai dari perkataan kasar dan perkelahian, namun ada juga kemungkinan bahwa anak-anak dan remaja meniru dan mengaplikasikannya pada kehidupan nyata.

Hal ini sesuai dengan teori belajar socia social behavior) dalam kaitannya dengan tayangan televisi menyebutkan bahwa, kekerasa itu cenderung dipelajari oleh pemirsa tayanga tersebut. Artinya, semakin banyak tayangan televisi yang menampilkan kekerasan atau pelecehan seksual dan lain sebagainya, anakanak atau orang dewasa akan melihat bahwa lirnya keker

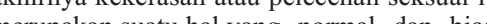
mias dalam kehidupan kita sehari-hari. Thorndike menyatakan bahwa belajar adalah proses interaksi antara stimulus dan respon. Stimulus adalah apa yang merangsang terjadinya kegiatan belajar seperti pikiran, perasaan, atau hal-hal lain yang dapat ditangkap melalui alat indera. Respon adalah reaksi yang dimunculkan peserta didik ketika belajar, yang dapat pula berupa pikiran, perasean, yau gera-

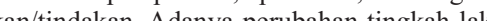
. ak yaitu yang dapat diamati, atau tidak konkri yaitu yang tidak dapat diamati.

Hasil penelitian ini juga menunjukkan adanya sumbangan efektif atau pengaruh yan diberikan intensitas menonton tayangan kekerasan di televisi terhadap kecenderungan agresifitas dalam penelitian ini sebesar $16,3 \%$. Ha ini menunjukkan bahwa selain intensitas meonton tayangan kekerasan di televisi masi banyak faktor lain sebesar $83,7 \%$ yang dapa mempengaruhi timbulnya kecenderungan agresifitas pada masa remaja, yakni antar lain pengaruh taraf kecerdasan emosi, lingkungan dan teman sebaya (peer group), hubungan dengan orang tua, tingkat sosial ekonomi, dan engan oran ebagainya.

Berdasarkan hasil penelitian yang telah dilakukan, maka saran yang dapat dikemukakan adalah sebagai berikut:

1. Bagi Siswa

Hendaknya lebih jeli dalam menonton tayangan di televisi dan tidak terlalu sering menghabiskan waktu dengan menonton televisi. Lebih banyak menghabiskan waktu dengan belajar atau kegiatan positif lainnya.

\section{Bagi Orang tua}

Orang tua dapat meluangkan waktu untuk mendampingi anak saat menonton tayangan televisi dan memberikan pengertian kepada anak saat menonton televisi. Orang tua juga dapat memberikan contoh yang baik, tidak menunjukkan sikap dan perilaku yang mengarah pada kekerasan.

3. Bagi Sekolah

Pihak sekolah dapat menghimbau para guru pengajar untuk mengarahkan dan memberikan bimbingan pada siswa dalam pemilihan tayangan di televisi serta memberikan banyak arahan mengenai perilaku yang adaptif baik di lingkungan sekolah maupun di masyarakat.

4. Bagi Peneliti Selanjutnya

Bagi peneliti selanjutnya yang ingin melakukan replikasi terhadap penelitian in disarankan untuk dapat mencari variabe lain yang dapat mempengaruhi variabel kecenderungan agresifitas pada che (a)

\section{DAFTAR PUSTAKA}

Arikunto, Suharsimi, 1998, Prosedur Penelitian: Suatu Pendekatan Praktek, Jakarta :Rineka Cipta

Azwar, Saifuddin, 2008. Penyusunan Skala Psikologi. Yogyakarta: Pustaka Pelajar.
2009. Metode Penelitian Yogyakarta: Pustaka Pelajar.

Baron, Robert A, \& Byrne, Donn .2000. Socia psychology-ninth edition. Boston; Allyn and Bacon

Berkowitz, L. 2003. Agresi 1, Jakarta: Pustaka Binaman Pressindo

Candiasa, IMade 2004 Analisis Butir Disertai Aplikasi dengan SPSS. Singaraja: Unit Penerbitan IKIP Negeri Singaraja.

Dahlan, S. 2009. Seri Statistika Untuk Kedokteran dan Kesehatan, edisi 4 Jakarta: Salemba Medika.

Danim, Sudarwan. 1995. Media Komunikasi Pendidikan. Jakarata: Bumi Aksara

Dayakisni, T. 1988. Perbedaan Intensi Prososia Siswa-siswi Ditinjau Dari Pola Asuh Orang tua. Jurnal Psikologi. No 1 Tahun Ke-XVI. Yogyakarta: Fakultas Psikologi Universitas Gajah Mada

Faisal, Sanapiah. 2005. Format-format Penelitian Sosial. Jakarta: PT. Raja Grafindo Persada.

Hadi, Sutrisno. 2000. Metodologi Research. Jilid 1. Yogyakarta: Andi Offset.

Http://depkominfo.com

Http://www.pikiranrakyat.co.id/index.php?act $=$ detail $=6982246 /$ diakses 20 maret 2012

Istiqomah, W, Kariyoso, Wibowo 2002. Psikologi Sosial. Jakarta: Karunika Universitas Terbuka Jakarta

Liebert, 1972. Some Immediate Effects of Televised Violence on Children's Behavior. Development Psychology, VI

Pratistio, Arif. 2004. Cara Mudah Mengatasi Masalah Statistik dan Rancangan Percobaan dengan SPSS 17. Jakarta: PT. Elex Media Komputindo.

Soetjiningsih. 2004. Tumbuh Kembang Remaja dan Permasalahannya. Jakarta: CV. Sagung Seto

Sugiyono. 2008. Metode Penelitian Kuantitatif Kualitatifdan $R \& D$. Bandung: Alfabeta. Uyanto, Stanislaus. 2009. Pedoman Analisis Data dengan SPSS. Yogyakarta: Grah Ilmu.

PSIKologia/ / Vol. : 2, No. : 1, Januuri 2013 